\title{
Socio-economic impacts of bamboo enterprises in the Mid-hills of Nepal: A case study on Pahari community at Badikhel Village, Lalitpur
}

\author{
M. Shakya Bajracharya ${ }^{1}$, S. Rajbhandary ${ }^{2}$ and A.N. Das ${ }^{3}$
}

\begin{abstract}
The present study investigates the associate enterprises involving bamboobased weaving and handicraft making at Badikhel Village Development Commitee, Lalitpur District, Central Nepal. It aims to assess the socio-economic importance of bamboo craft making on Pahari community at Badikhel. Forty households were randomly selected for questionnaire survey from the areas with higher density of bamboo entrepreneurship practiced. Perceived stakeholders were interviewed to examine their roles and to find out the contribution of bamboo enterprises to household income. Group discussions on issues of bamboo cultivation and management were conducted following RRA and PRA techniques. It was found that Badikhel impregnates four species of bamboo belonging to two genera viz. Bambusa and Drepanostachyum and are important and traditional source of livelihood for the Paharis, one of the ethnic groups in the study area. An average bamboo handicraft maker obtained NRs. 1000 to NRs. 5000 per month from the cash sales of assorted handicrafts. However, no significant bamboo management practices were carried out by the entrepreneurs. Three out of four community managed forests in the study area planted only Bambusa nepalensis as per local demand. Since stakeholders' involvement in actual promotion of bamboo handicraft industry and bamboo management is meager there is an urgent need for the formation of a larger association of bamboo users for the growth and development of the bamboo entrepreneurship in the area.
\end{abstract}

Key words: Socio-economics, bamboo entrepreneurship, Paharis, Bambusa, Drepanostachyum

$\mathrm{B}$ amboo is one of the important non-timber forest products (NTFPs) cultivated widely in the world (FAO, 1978). It has intimately been associated with human beings since time unknown. In Nepal, bamboos are found in almost all its parts-natural or cultivated with twelve genera and more than fifty-three species (Stapleton, 1994; Karki et al., 1995; Das, 1999; Joshi and Amatya 1999; Das, 2004).They are the important component of rural farming system and play a critical role in rural economy helping to sustain livelihoods of the many rural households that include socially and economically disadvantaged group (Das, 1992; Thapa et al., 1998; Das, 1999). Cultivation of bamboos is a common practice on private farmlands. The multi-purpose species has been increasingly introduced in community forests (Das, 2002).
Bamboo entrepreneurship is one of the key instruments for the upliftment of socio-economic status of poor and under privileged people in Nepal. Bamboo craft makers design various bamboo architectures in assistance with simple basic tools prepared locally. An estimation of about 3.3 million farming families are somehow involved with bamboo sub-sector either as producers or as users of bamboo- based products (Pant, 2006). Development and encouragement of cottage industries based on bamboo thus have a very high potential of providing the locals with much needed cash income and making a very important contribution to their household economy (Poudyal, 1992; Karki et al., 1995; Sherchan et al., 1996). Further, it can contribute to the regional and national economy. However, due to the lack of conducive policy and government's

\footnotetext{
${ }^{1}$ St. Mary’s College, Kathmandu, Nepal. E-mail: merinashk@hotmail.com

${ }^{2}$ Central Department of Botany, Kathmandu, Nepal.

${ }^{3}$ Department of Plant Resources, Kathmandu, Nepal.
} 
support, disorganized market and limited skills, bamboo-based economy contributes only $1-2 \%$ to the national GDP (Karki et al., 1998).

The present study attempts to investigate the relationship between the bamboo-based enterprises and the Paharis, the ethnic community at Badikhel Village Development Committee (VDC). The research thus brings out in light, the socioeconomic impacts of traditional craftsmanship in improving the living standard of these people.

\section{Materials and methods}

\section{Study area}

Badikhel VDC lies in the northern part of Lalitpur district between $27^{\circ} 36^{\prime} 04.88^{\prime \prime} \mathrm{N}$ latitude and $85^{\circ} 20^{\prime} 48.96^{\prime \prime} \mathrm{E}$ longitude, occupying approximately 905.2 hectares with an elevation of $1290-1710 \mathrm{~m}$ above sea level. It is bordered with Godavari in the east and the north, Jharuwarasi and Chapagaon in the west and Lele and Chapagaon in the south (Fig. 1). According to the CBS (2001), the total population of Badikhel VDC is 3212. It has a predominant of an ethnic group, the Paharis occupying approximately $55.22 \%$ (1774) of the total population. Besides, Brahmins and Chettries cover about $40 \%$ while the rest $10 \%$ of the population comprises of the minor caste groups like Newar, Gurung, Rai, Magar, Kami, Damai and others (CBS, 2001).

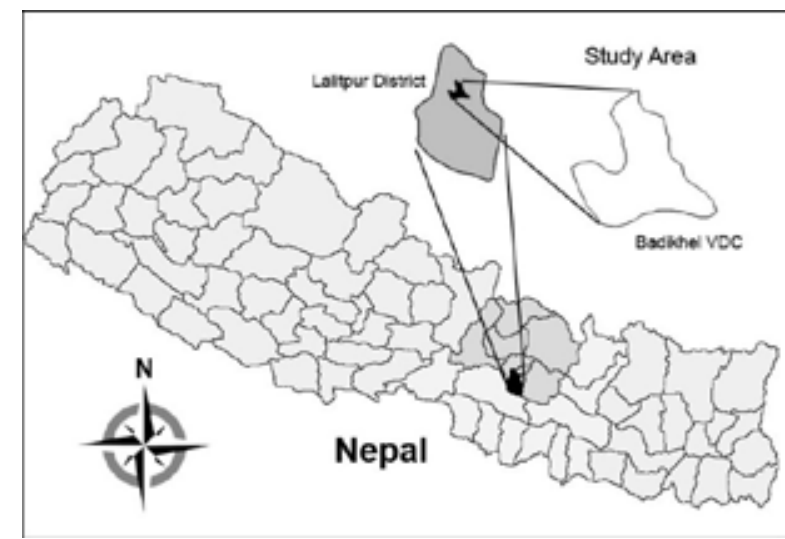

Fig. 1: Map showing the study area

\section{Research methods}

The socio-economic survey was conducted in the study area in the year 2006/2007 during summer and rainy seasons (April- August). The random sampling method was used as sampling frame. Out of 300 Pahari households (HHs), 40 HHs with
285 inhabitants were selected as sample units and interviewed. Each $\mathrm{HH}$ was considered as a sample unit. Selection of the areas was done on the basis of the high density of bamboo entrepreneurs as developed locally in a participatory way, which include bamboo craft makers, growers, traders and sellers (Table 1).

\section{Table 1: Distribution of sampled households}

\begin{tabular}{cccc}
\hline S.N. & Ward no. & $\begin{array}{c}\text { No. of } \\
\text { HHs }\end{array}$ & $\begin{array}{c}\text { Sampled } \\
\text { HHs (\%) }\end{array}$ \\
\hline 1. & 4 & 10 & 25.0 \\
2. & 5 & 9 & 22.5 \\
3. & 6 & 8 & 20.0 \\
4. & 7 & 5 & 12.5 \\
5. & 8 & 8 & 20.0 \\
Total & & $\mathbf{4 0}$ & $\mathbf{1 0 0}$ \\
\hline
\end{tabular}

Source: Field survey, 2006/07

Participatory methods such as RRA/PRA, focus group discussion, semi-structured questionnaire and key informant interviews were used to obtain the qualitative and the quantitative data. The participatory assessment was done as a crosscheck by conducting group discussions in various wards asking different questions related to plant identification, their uses, habitat, distribution, local name, cultivation, harvesting period, products manufactured, methodology and technologies practiced, income generation and the existing bamboo conservation practices.

Bamboo specimens found in the area were collected in summer and rainy seasons from April to August in 2006. They were identified with the help of various standard literatures (Stapleton, 1994; Tiwari, 1992; Das, 2004) and with the guidance of bamboo experts. Preservation of these specimens was done using standard herbarium techniques of Stapleton (1994) and Poudyal (2006).

\section{Results and discussion}

\section{Distribution of bamboo species}

From the survey, it was found that Bambusa nepalensis and Drepanostachyum annulatum occurred in natural as well as in cultivated forms, whereas Bambusa balcooa and Bambusa nutans subsp. nutans existed only in cultivated stands (Table 2). 
Table 2: Distribution of bamboos in Badikhel VDC and their local names

\begin{tabular}{lll}
\hline Latin name & $\begin{array}{l}\text { Local } \\
\text { name }\end{array}$ & $\begin{array}{l}\text { Distribu- } \\
\text { tion }\end{array}$ \\
\hline $\begin{array}{l}\text { Bambusa nepal- } \\
\text { ensis }\end{array}$ & Tama bans & WC \\
$\begin{array}{l}\text { Bambusa nutans } \\
\text { subsp. nutans } \\
\text { Bambusa balcooa }\end{array}$ & $\begin{array}{l}\text { Taru bans } \\
\text { Dhanu }\end{array}$ & $\mathrm{C}$ \\
$\begin{array}{l}\text { brepans } \\
\text { annalatum }\end{array}$ & $\mathrm{C}$ \\
$\begin{array}{l}\text { C: cultivated; W: Wild; WC: Wild as well as } \\
\text { cultivated }\end{array}$ & \\
\hline $\begin{array}{l}\text { Source: Figlold } \\
\text { Burvey }\end{array}$
\end{tabular}

Source: Field survey, 2006/07

To state the pattern of bamboo distribution in the study area, five categories of frequency class stated by Manandhar and Bhattarai (1998) were used, which are given below. It was also noticed that Bambusa nepalensis was the most commonly occurring species rating highest in abundance, followed by $D$. annulatum, $B$, nutans subsp. nutans and B. balcooa (Table 3).

Table 3: Distribution of bamboos in different wards of Badikhel VDC

\begin{tabular}{ccccc}
\hline $\begin{array}{c}\text { Ward } \\
\text { no. }\end{array}$ & $\begin{array}{c}\text { B. nep- } \\
\text { alensis }\end{array}$ & $\begin{array}{c}\text { B. } \\
\text { nutans } \\
\text { subsp. } \\
\text { nutans }\end{array}$ & $\begin{array}{c}\text { B. } \\
\text { bal- } \\
\text { cooa }\end{array}$ & $\begin{array}{c}\text { D. an- } \\
\text { nula- } \\
\text { tum }\end{array}$ \\
\hline 2 & C & F & R & F \\
3 & C & - & - & C \\
4 & $\mathrm{~A}$ & - & - & C \\
5 & $\mathrm{~A}$ & - & - & $\mathrm{C}$ \\
6 & $\mathrm{~A}$ & $\mathrm{~F}$ & - & $\mathrm{F}$ \\
7 & $\mathrm{C}$ & - & - & $\mathrm{F}$ \\
8 & $\mathrm{~A}$ & $\mathrm{~F}$ & - & $\mathrm{C}$ \\
9 & $\mathrm{C}$ & $\mathrm{C}$ & - & $\mathrm{C}$ \\
\hline
\end{tabular}

Source: Field survey, 2006/07

A: abundant with more than 20 clumps; C: common with 10-19 clumps; F: few having 3-9 clumps and $\mathrm{R}$ : rare with 1-2 clumps; - Absent

\section{Utilization of bamboo species}

Bamboos are one of the very important sources of livelihood for the Paharis. The traditional craftsmen had used all the existing bamboo species in one or the other ways. But their dependency towards $B$. nepalensis was higher than other existing species as this species was the main raw material they used for their bamboo-based craft making (Table 4).

Table 4: Bamboo species preferred among the respondents

\begin{tabular}{lcccc}
\hline Items & $\begin{array}{l}\text { B. nepal- } \\
\text { ensis }\end{array}$ & $\begin{array}{l}\text { B. } \\
\text { nutans } \\
\text { subsp. } \\
\text { nutans }\end{array}$ & $\begin{array}{l}\text { B. bal- } \\
\text { cooa }\end{array}$ & $\begin{array}{l}\text { D. } \\
\text { annula- } \\
\text { tum }\end{array}$ \\
\hline Weaving & $* * *$ & $*$ & - & $*$ \\
material & & & & \\
Racks & $* * *$ & - & - & $*$ \\
$\begin{array}{l}\text { Edible } \\
\text { shoots }\end{array}$ & $* * *$ & - & - & - \\
$\begin{array}{l}\text { Fodder } \\
\text { Con- }\end{array}$ & $* * *$ & $*$ & - & $* *$ \\
struction & & $*$ & - & - \\
$\begin{array}{l}\text { Fencing } \\
\text { Soil } \\
\text { stabili- } \\
\text { zation }\end{array}$ & $* * *$ & $*$ & - & - \\
\hline
\end{tabular}

Source: Field survey, 2006/07 Highest $(* * *)$, Medium (**), Lowest (*), Nil (-)

Various bamboo artifacts like Nanglo (flat and rounded plate), Chalno (Sieve), Doko (Basket for carrying loads), Dalo (Basket for storage purpose), racks, dustbins, and few other products like photo frames, flower vase, hand bags, decorative items were made from B. nepalensis. Stapleton (1994) considers it as a multipurpose species used for weaving, construction and for edible shoots. Das (2004) has reported the use of this species for weaving different types of baskets and grain stores in the hills.

Besides craft making, the locals used bamboo resources for other benefits like in construction, soil stabilization, fencing, as fodder, vegetables and for many daily household purposes and field works. Similar utilization of B. nepalensis has been reported from the Mid-hills and the Terai of eastern Nepal and in central and western Nepal by Das $(1999,2004)$ and Poudyal (2006), whereas B. nutans subsp. nutans and B. balcooa in the 
study area were scarcely used to their potency due to limited availability and little knowledge. In comparison, $D$. annulatum was found to be used a little more than sparingly yet its utility was secondary to $B$. nepalensis.

\section{Socio-economic assessment of bamboo-based work in the study area}

Bamboos had received high social and economical values for their role in the lives of the Pahari community of the study area. It was found that not a single household had one-man entrepreneurship, rather, $100 \%$ employees belonged to their own family with each family having in average, three members involved in the business. This showed that the bamboo enterprises in the study area played an important role in employment generation. Kattel et al. (2007) has also reported similar condition from eight Municipal towns (Biratnagar, Birgung, Dhading, Dhankuta, Dharan, Nepalgunj, Pohhara and Surkhet) and surrounding areas of Nepal.

Further, the study revealed that the literacy percentage of the bamboo entrepreneurs in the study area was $47.5 \%$ with the rest $52.5 \%$ illiterate whereas Kattel et al. (2007) reported $87 \%$ of literacy level in his study areas. Similar condition is reported from Phongam village in Thailand where nearly all the bamboo entrepreneurs are qualified with primary level education (Thammincha, 1988). Muraleedharan and Rugmini (1988) have reported similar educational status among $47-80 \%$ bamboo entrepreneurs in Kerala. Thus, the facts clear out that it is a right choice for the educationally underprivileged Paharis for self-interdependent and improving their living standard.

Desapite the bamboo entrepreneurship owed and governed by males the working team involved both sexes in an equal ratio. As bamboo craft making can be done in harmony with domestic tasks, it is taken as an extension of household activities. The situation is similar in the eastern Nepal among many poor women (Das, 1999). FAO (1978, 1990) has reported the heavy involvement of women in forest-based smallscale enterprises (FBSSEs) in many developing countries. Thus, the traditional business has been providing a means for upgrading the living condition of Pahari women in male dominated society.
About $80 \%$ of the bamboo entrepreneurs in the study area were found operating the business since last 30 years and more. This showed their dependence on bamboo resource. Das (1999) reported similar condition in the people, especially the socially and economically disadvantaged group in the Terai and the Mid-hills of Nepal. Pun (2007) has reported the bamboo craft making business as life sustaining among the lower caste groups like Dom, Dalit, Kami, Damai, Sarki, etc. in Siraha district.

\section{Availability of bamboo as the raw material}

Like most of the traditional industries in the developing countries, the bamboo enterprises in the study area sufficient supply of raw materials. It was found the total annual production of the community managed forest ranged $200-405$ culms whereas the annual consumption of the sampled 40 households reached only 6863-8850 culms. Furthermore, the small size of landholding put constraints in bamboo growing. The average size of landholding per bamboo entrepreneur in the study area was only 0.43 hectares, while some were landless. Karki et al. (1998) states that landholding is one of the main factors determining the household decision for bamboo cultivation. Thus, few clumps grown in private lands are insufficient to meet the demand.

With only $5 \%$ of the required raw material available in the area, the rest $95 \%$ was found to be fulfilled from the external sources. If only the raw material could be made available locally, the annual income of the bamboo entrepreneurs can improve tremendously because the maximum price per culm bought from the local village ranged from NRs.25-100 whereas that bought from outside ranged from NRs.150-200.

There exists the traditional method of bamboo propagation by planting culm offsets with rhizomes in the study area, the method being expensive and time consuming, Das (2004) has stated it to be unsuitable for large sized bamboo. Based on the demand, the villagers had given preference to the plantation and conservation of B. nepalensis. This is due to poor knowledge of bamboo characteristics, properties and proper information flow; the craft makers are unaware of high end use of locally available species (Das, 2001). 


\section{Production and contribution of bamboo- based enterprises}

Majority of the entrepreneurs in the study area were found to deal with the traditional household appliances like Nanglo, Chalno, Doko and Dalo. Few modern products like racks and dustbins had helped them to raise their economical status (Table 5).

Table 5: Major Products dealt by the respondents and their demand

\begin{tabular}{lc}
\hline \multicolumn{1}{c}{ Items } & Demand rank \\
\hline Nanglo/ Chalno & 1 \\
Racks & 2 \\
Doko / Dalo & 3 \\
Dustbin & 4 \\
Photo frame, decorative & 5 \\
items, and others & \\
\hline
\end{tabular}

Source: Field Survey, 2006/07

It was found that a profit of NRs.125 was made by selling a single piece of dustbin, which is equivalent to the profit made by selling 4-5 pieces of Nanglo or Chalno. Likewise, even more profit was obtained by $12.5 \%$ of the total surveyed entrepreneurs dealing with innovative valueadded products like photo frame, bag, flower vase, etc (Table 6). However, these entrepreneurs too were not fully involved as they suffered from the problem of poor marketing channels and lack of information flow. However, limited knowledge on marketable craftsmanship skill and lack of modern scientific tools and techniques also hindered the growth and development of their business influencing the productivity both quantitatively and qualitatively.

The market of bamboo products and their sales were also linked to season. The highest sales were during October to December, the festive (Tihar) and marriage seasons. April to December was the moderate selling months and January to March the low selling months. Sales were also related to agricultural seasons. Cultural diversification imposed a considerable amount of effect on the bamboo product sale in the market.

The cash income generated from the sales of woven products and crafts was an important livelihood of the Pahari community, however
Table 6: Economical account of some bamboo products

\begin{tabular}{|c|c|c|c|}
\hline $\begin{array}{l}\text { Name of } \\
\text { items }\end{array}$ & $\begin{array}{l}\text { Average } \\
\text { cost price } \\
\text { (NRs/ } \\
\text { piece) }\end{array}$ & $\begin{array}{l}\text { Production } \\
\text { rate (Piece/ } \\
\text { person) }\end{array}$ & $\begin{array}{l}\text { Aver- } \\
\text { age } \\
\text { selling } \\
\text { price } \\
\text { (NRs/ } \\
\text { piece) }\end{array}$ \\
\hline $\begin{array}{l}\text { Small Nan- } \\
\text { glo (20” } \\
\text { diameter) }\end{array}$ & 15 & $1 / 2$ day & 35 \\
\hline $\begin{array}{l}\text { Big Nanglo } \\
\text { (22" diam- } \\
\text { eter) }\end{array}$ & 25 & 1day & 60 \\
\hline Rack & 80 & 1day & 100 \\
\hline Dustbin & 100 & 2days & 225 \\
\hline Chalno & 20 & $1 / 2$ day & 40 \\
\hline Small Doko & 50 & $11 / 2$ days & 85 \\
\hline Big Doko & 100 & 2days & 150 \\
\hline Small Dalo & 50 & $11 / 2$ days & 85 \\
\hline Big Dalo & 70 & $21 / 2$ days & 115 \\
\hline $\begin{array}{l}\text { Photo } \\
\text { frame }\end{array}$ & 50 & $1 / 4$ day & 225 \\
\hline Handbag & 65 & $1 / 2$ day & 135 \\
\hline
\end{tabular}

Source: Field Survey, 2006/07

the monthly turnover being not more than NRs.5000/- per month. Maximum entrepreneurs (37\%) had their monthly income ranging from NRs.2001-NRs.3000 (Fig. 2). On an average, bamboo crafts makers worked for 9 months in a year and earned NRs.27,000. However, this income was in contrast to the income of Terai crafts makers who earn an average of NRs.45,000 working for 9.9 months in a year (Pun, 2007). Likewise, the bamboo crafts makers of Dhankuta earn an average annual income of

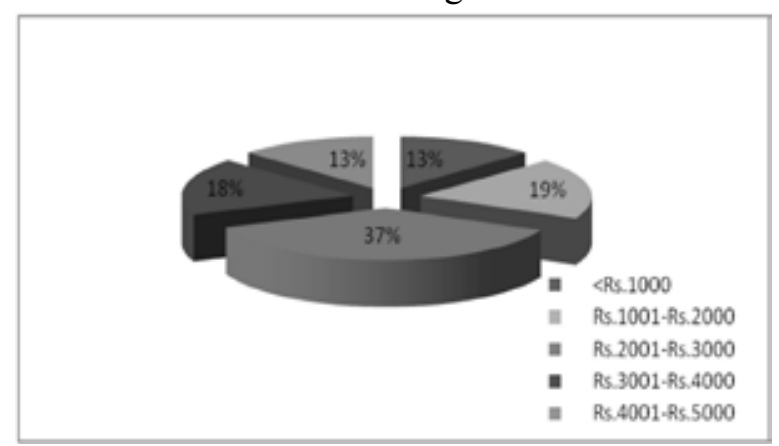

Fig. 2: Monthly turnover of bamboo entrepreneurs 
NRs.5,500 working for 5.6 months in a year (Das, 2002). Further, Kattel et al. (2007) has stated that the average yearly income of the bamboo entrepreneurs is NRs. 1,000,00.

\section{Conclusion}

Bamboo enterprise has been a livelihood strategy for Paharis, one of the socially and economically disadvantaged groupsof Nepal residingin Badikhel for decades. Beside contributing significantly to the livelihood security, bamboo handicraft making based on their traditional practices is also assisting in promotion of indigenous knowledge and technology, development of craft-based cottage industry and improvement in socioeconomic condition of marginalized and poor Paharis especially women and landless families in the area studied. Such traditional utilization of bamboos for domestic as well as for commercial purpose is helpful in stimulation of indigenous entrepreneurship.

The bamboo enterprises of the area studied, however, suffer from many problems. No profound bamboo management is practiced in both handicraft making and bamboo cultivation. Consequently, the demand of raw material is unable to be fulfilled with its huge percentage (95\%) found to have derived from the outer sources. Further, lack of introduction of modern tools and technology and poor market information is found as another hindrance in further progress and promotion of this traditional business in the area. Currently, except the community forest user groups, there are no other stakeholders working with the communities in sustainable management of bamboos. Nevertheless, in spite of these drawbacks, the business helps the local bamboo entrepreneurs to generate an additional earning. Under proper supervision and management of this traditional craftsmanship, the enterprises possess a tremendous potential in uplifting the socioeconomic condition of unprivileged rural lives of the Paharis. This "green gold" should be recognized and user groups should be made well aware of its sustainable management and utilization.

\section{References}

CBS. 2001. Statistical Year Book of Nepal 2001. Central Bureau of Statistics, Kathmandu, Nepal.
Das,A.N. 1992. The Potential of Bamboo Growing in Rural Development Forestry in Nepal. M.Sc. (Forest Management) Dissertation, University of Aberdeen, UK.

Das, A.N. 1999. Socioeconomics of Bamboos in Eastern Nepal. PhD Thesis, University of Aberdeen, UK.

Das, A.N. 2001. Bamboo: Species for economic prosperity, environmental conservation and rural development in Nepal. Nepal Bamboo Update: 2 (1):3-4.

Das, A.N. 2002. Bamboo growing and its market development potential for sustaining rural livelihoods and poverty reduction in eastern Nepal. Banko Janakari, 12 (1): 8-19.

Das, A.N. 2004. Manual on Bamboos of Nepal. Community Forestry Component. Tree Improvement and Silviculture, Ministry of Forests and Soil Conservation, Kathmandu, Nepal.

FAO. 1978. Bamboo forest news for Asia and the Pacific. Food and Agricultural Organizations, Bangkok, Thailand.

FAO, 1990. Case studies in forest based small scale enterprises in Asia: Rattan, Matchmaking and Handicrafts. Campbell Jeffery (edit.). Community Forestry Case Study No. 4. FAO, Bangkok, Thailand.

Karki, M.B. and Karki, J.B.S. 1995. National Bamboo and Rattan Information Database, Nepal, Tribhuvan University, Institute of Forestry, Pokhara, Nepal.

Karki, M.B., Sherchan, G.R. and Karki, J.B.S. 1998. Extensive Bamboo Production and Consumption in Eastern Nepal: a case study. INBAR working paper No. 17. INBAR, Beijing, China.

Kattel, A.,Parajuli, B. and Tuladhar, G.R. 2007. A Study of the Bamboo and Rattan Sub sector in Eight Municipal Towns and Surrounding Areas of Nepal. INCON Pvt. Ltd., Lalitpur, Nepal.

Manandhar, R. and T. Bhattarai. 1998. Distribution of bamboo in Kathmandu Valley. Banko Janakari 8 (1): 19-23.

Muraleedharan, P.K. and Rugmini, P. 1988. Problem and prospects of traditional bamboobased Industry in Kerala: 328-333. In Bamboos Current Research, Proceedings of the 
International Bamboo Workshop (eds.), Rao, I.V.R., Gnanaharan, R., Sastry, C. B., Cochin, India.

Pant, A. 2006. Accessing Competitiveness of Bamboo Sub Sector. GTZ PSP/RUFIN, Kathmandu, Nepal.

Poudyal, P.P. 1992. Bamboos- Field Manual for Community and Private Forestry in Nepal. Part II Field Document No 20, HMG/FAO/ UNDP, Community Forestry Development Project (Phase II), Kathmandu, Nepal.

Poudyal, P.P. 2006. Bans ko shikshya. (Education on Bamboo). Swayambhu Environmental Education 171-202.

Pun, B.R. 2007. Siraha as Potential District for Bamboo Promotion in Nepal. Submitted to INBAR for International Seminar on Bamboo for Sustainable development, Kathmandu, Nepal.

Sherchan, G.P., Karki, M.B., Karki, J.B.S. 1996. Case Study in Extensive Collection, Production, Utilization and Marketing of Bamboo in Eastern Nepal. A report submitted to INBAR/IDRC, Beijing, China.
Stapleton, C. 1994. Bamboos of Nepal: An Illustrated Guide. Royal Botanical Gardens, Kew, London, UK.

Thammincha, S. 1988. Some aspects of bamboo production and marketing: . In Bamboos Current Research. Rao, I.V.R., Gnanaharan, R. and Sastry, C.B. KFRI, India and IDRC, Canada, 320-327.

Thapa, H.B., Das, A.N. and Oli, B.N. (1998). Growth performance and culm production of bamboo at the Eastern Terai, Nepal. Banko Janakari 8 (1): 13-18.

Tiwari, D.N. 1992. A Monograph on Bamboo. International Book Distributors, Rajpur Road, Dehradun 248001, Uttaranchal, India. 